\title{
在室者の調整行動を利用した省エネ空調制御システムに関する研究 A STUDY ON ENERGY SAVING AIR-CONDITIONING CONTROL SYSTEM UTILIZING ADJUSTMENT BEHAVIOR OF OCCUPANTS
}

\author{
荻野 司*, 酒井浩介**, 志田智**, 須 永修通*** \\ Tsukasa OGINO, Kosuke SAKAI, Satoshi SHIDA \\ and Nobuyuki SUNAGA
}

\begin{abstract}
In this study, an active energy-saving control system installed on a SaaS type BEMS has been examined. This system is easy to be introduced to small and medium-sized buildings by SaaS type BEMS, configuring a virtual BEMS depending on the physical equipment setting of the building. This active energy-saving control of air-conditioning makes an energy saving possible by controlling of indoor air-conditioning unit and is also characterized by its method to reduce the room conditioning deterioration by sensing the occupants' on/off operation behavior onto the air-conditioning. This paper describes the result of the developed air-conditioning energy saving control system by the summer season data of an office space in a medium sized building.
\end{abstract}

Keywords: Energy saving, HVAC control, BEMS, Thermal sensation, Office buildings, Environmental comfort 省エネ，空調制御，BEMS，温熱感覚，オフィスビル，快適環境

\section{1. はじめに}

現在、省エネルギーと地球温暖化ガス放出の低減は、世界的な課 題である。日本では、東日本大震災以降、この対策は急務となって おり、社会全体の省エネを進めるため、商業施設、オフィスビルな どの多様な施設、建物において、新築、既存、大規模、小規模にか かわらず取り組まれている。設備関連では、高効率機器への導入促 進補助制度に加えて、既存設備機器の運用による省エネを目的とし て、BEMS (Building Energy Management System) 導入が推進 されている ${ }^{1)}$ 。しかし、BEMSの導入実態をみると大規模建物向け が中心で未だ広く普及するに至っておらず、中小規模建物に向けた 簡易BEMSの開発が必要との提言が示されている2)。BEMSは、異 なる用途や様々な設備機器への対応が必要なため、システム規模が 大きくなる傾向がある。そのため投資対効果を考えると、電力削減 額としての省エネ効果が小さい中小規模建物への導入が進みにくい。

一方、無理な省エネは業務効率を悪化させる原因となり、省エネ と快適性の両立が望まれる。省エネを図りながら個々の要望を満足 させる空調システムとして、パーソナル空調方式が期待されている が、新築建物が中心で適用には制限がある。既存空調設備でも適用 しやすい簡便な手法として、発停制御による間欠運転方式がある。 坊垣ら ${ }^{3)}$ 、宋 ${ }^{4)}$ の研究によれば、省エネを図りながら室温一定によ る連続運転と同等の快適性が得られる可能性を示唆しているが、 日々の温熱環境の変化や在室者の温熱環境改善要望 (以降、「温熱要 望」）を反映させた制御方式の提案には至っていない。また、熱的快 適性指標であるPMV (Predicated Mean Vote) を利用して外部環境 を考慮した空調制御方式らも提案されているが、同一空間における
執務室内の不均一性への対応が難しく6)、在室者の温熱要望への対 応も課題である。村上ら ${ }^{7)}$ は、在室者の温熱要望申告をパーソナル コンピュータにて取り入れ、在室者全体の特性に適応する空調制御 方式を考案し、業務形態、性別など様々な特性を有する在室者に対 応する制御ロジックを検討しているが、定量的な省エネ性能の検証 や総合的な制御方式の提案には至っていない。

そこで本研究では、既存の中小規模建物にも容易に設置でき、建 物内の設備変更にも対応可能なSaaS型BEMS（以降、S-BEMS）を 用いて積極的に省エネを図る制御システム（以降、「アクティブ省エ ネ制御システム」）を考案し、その効果や制御性について検討してい る。アクティブ省エネ制御は積極的に自動で省エネを図るもので、 本報では空調に関する制御について述べるが，照明についても検討 している。本報の空調アクティブ省エネ制御は、空調室内機の稼働 時間を減らすことで積極的に省エネを図るが、在室者に空調の ON/OFF（調整行動）を許可し、その調整行動を空調稼働リレーの 状態から把握して運転間隔（稼働時間）を自動的に調整し快適性を 損なわないようにしようとするものである。すなわち、この制御で は、気象状態や在室者の属性、着衣量、温冷感、心理状態などを細 かく把握して空調制御を行うのではなく、それらの結果としての調 整行動を空調制御に反映させている。

本報では、まずこのS-BEMSを用いたアクティブ省エネ制御シス テムの構成と特徴を示す。次に本システムを中規模テナントビル内 のオフィスに導入し、その中の会議室に空調のアクティブ省エネ制 御を行った場合の効果について、実測と在室者へのアンケートから 検討した結果を示す。

\footnotetext{
本論文は，既発表論文(10)(11)(12)で発表した内容に基いて加筆・修正したものである。

*** 首都大学東京都市環境科学研究科建築学域 教授・博士 (工学) 


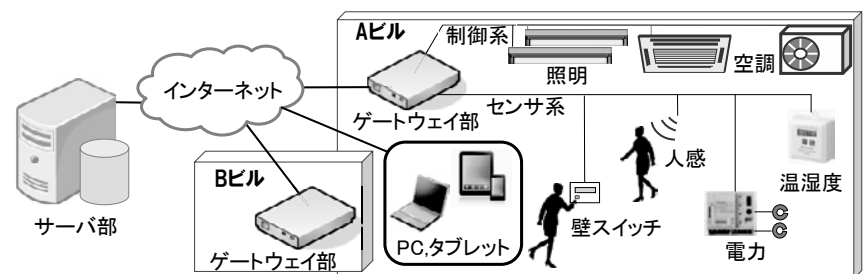

図 1 SaaS 型BEMS を利用したアクティブ省エネ制御システム

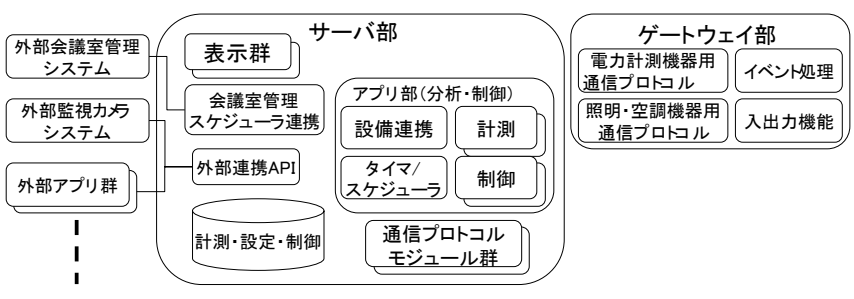

図2 SaaS型BEMSソフトウェア機能ブロック図

2. SaaS型BEMSによるアクティブ省エネ空調制御システム

\section{1. SaaS型BEMSの概要}

図 1 にS-BEMSを利用したアクティブ省エネ制御システム構成図 を示す。また、図 2 にS-BEMSのソフトウェア機能ブロック図を示 す。ビル内に設置するゲートウェイは、対象建物内の設備機器との 通信・制御を行う。電力計測装置、温湿度計、人感センサなどのセ ンサ系、照明、空調室内機、室外機などの制御系と、シリアルまた はイーサネットによって接続され、個別制御が可能である。なおケ ーブルなどが無い場合は新たに設置する必要がある。設備機器との 通信プロトコルはメーカや機能の違いにより多種多様であるが、対 象建物内の設備機器に必要な通信プロトコルモジュールのみゲート ウェイ部にサーバ部からダウンロードして使用する。建物内の設備 機器が改修、追加された場合には、従来のBEMSでは修正工事が必 要なこともあったが、本S-BEMSでは、不足する通信プロトコルモ ジュールのみサーバ部からダウンロードすれば良く、設備機器の改 修、追加、廃棄に対して自在に対応できる。

サーバ部には、各々の建物で計測された電力、室内温湿度などを 機器毎、期間毎に蓄積、表示する機能や、照明や空調の制御機能、 センサと設備機器の動作連携機能、タイマ、スケジューラなどが機 能毎にアプリケーションとして用意されている。建物の規模によら ず、必要な機能に対応したアプリケーションを選択することで、最 適なBEMSを構成できる。さらに、外部システムからの情報を取得 する機能もあり、本実証実験では、既存の会議室管理システムから 会議予定情報を取得することで、予約されている時間帯に対して空 調のアクティブ省エネ制御を行った。

\section{2. 在室者の調整行動を利用したアクティブ省エネ空調制御}

中小ビルにおける空調機器は、最大負荷により設計されることが 一般的である。そのため、気候の変動やオフィス内在室者の温冷感 などが反映されにくいので、快適性確保の面からも適切な運用が重 要となっている。また、従来の室内温度制御では、専ら人（管理者 及び在室者）による空調運用が一般的であるが、快適性の維持と省 エネの両立を図るのは難しく、外気温や日射などの影響を避けるた めに、過剩な運用となっていることが多い。さらに、日々の業務状 態の違い、個人の温冷感の違いから、在室者の要求と運用がマッチ

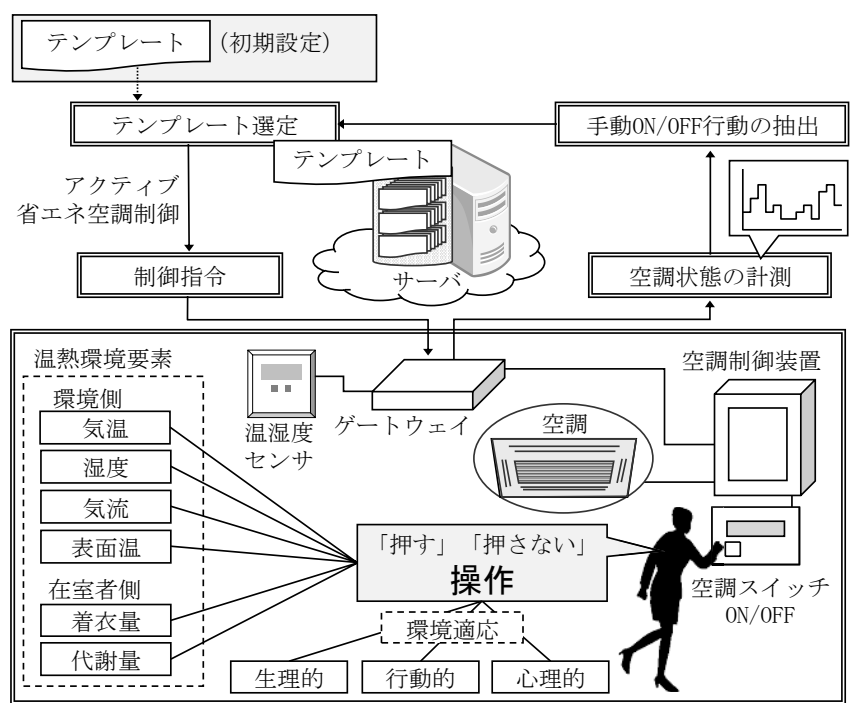

図3アクティブ省エネ空調制御システム動作概念図

していないことも多い。このような課題を解決するためには、多様 な在室者の要求を計測できれば、内外部環境の影響や在室者の温熱 状態に応じた空調制御ができ、快適性を維持しながら積極的な省工 ネを実現できる可能性がある。

そこで筆者らは、在室者の総合評価としての空調への要求（温熱 要望）を定量的に把握する方法として、在室者の手動による空調操 作に着目した。図 3 に概念図を示す。室内の温熱環境は時々刻々変 化しており、在室者が期待する快適範囲に達していない場合もある。 そのような状況における在室者による空調操作は、温熱環境を適正 に調整する行動として捉えることができ、その時点での室内環境の 満足・不満足の境界点と考えることができる。すなわち、人は不快 にならないように温熱環境 6 要素と生理・行動・ 心理の環境適応 3 要素を総合して調整行動を行うと考えられるが、本システムは、こ の調整行動を空調制御に利用するものである。

中小規模建物への導入を容易にするため、本システムでは、室温 制御よりも容易に制御が可能な室内機の発停制御により、空調の稼 働削減 (省エネ) を行う。温熱環境に応じて空調の稼働削減量を変 化させる必要があるので、異なる稼働削減量毎に空調稼働モード (以 降、モード）を設定し、各モードの稼働削減量に従った空調室内機 の $\mathrm{ON} / \mathrm{OFF}$ 制御を記述したテンプレートを用意している。図 4 にア クティブ省エネ空調制御の動作例を示す。図では、15 分 ON、10 分 $\mathrm{OFF}$ の空調 $\mathrm{ON} / \mathrm{OFF}$ 制御を記述したテンプレートに従って空調 が制御されている。予約システムより取得した会議予約時間を利用 して、使用開始の 5 分前に空調が ONされ予泠が実行される。使用 開始から 10 分後に空調が OFFされるが、その後、在室者の調整行 動によって空調が ONされた場合には、次の空調 OFF まで空調が

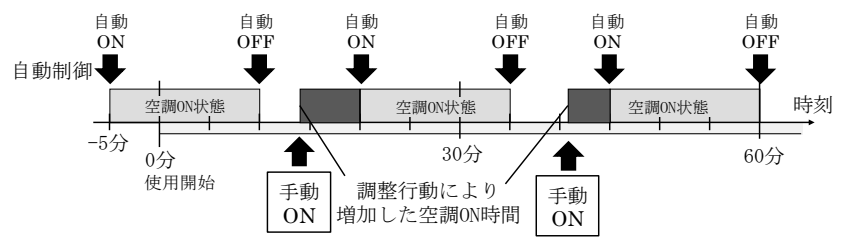

図 4 アクティブ省エネ空調制御による空調 ON/OFF 例 
稼働し、その時点での室内環境が改善される。但し、所定の稼働削 減率よりも調整行動により増加した空調 ON 時間だけ稼働削減率は 低下寸る。この手動による空調 ON（または OFF）操作回数から、 調整行動（手動操作）が少なくなるようなテンプレートを選定する ことで、次回から在室者の要望に応じた空調制御を行う。なお、調 整行動が無い、もしくは少ない場合には、省エネ方向になるテンプ レートを選定する。すなわち、図 3 上段に示すように、初期状態の テンプレートで制御を開始するが、その後、調整行動である空調 $\mathrm{ON} / \mathrm{OFF}$ の時間当たりの回数がモード選定時にフィードバッグさ れ、新たに最適なテンプレートが選択される。

\section{3. 夏季におけるテナントオフィスでの実証結果}

\section{1. 実証実験の方法}

都内Nビルにおいて、2013年7月8日より2013年9月30日に実証実 験を行った。建物概要は表 1 の通り、標準的なテナントビルで6階フ ロアの会議室、執務室において本システムによる省エネ実証実験を 実施した。システムの構成は、センサ系として、人感センサ検出機 能と調整行動の把握機能注 1 、 、制御系として、空調発停機能、空調の 発停を記述したテンプレートによる間欠運転機能、会議室管理シス テム連携機能、人感センサ連携機能および調整行動を空調制御にフ イードバックする機能とした。また、温熱環境の把握、省エネ状態 を評価するために、温湿度、グローブ温度、電力計測の各機能も追 加した。図5に各室外機の対象範囲、空調室内機、温湿度計注2)、グ ローブ温度計注3) の設置位置を示す。また各会議室の天井に人感セン サも設置した。空調制御は、室内機の発停のみで行い、室内機用の 発停リレー注4)で制御する。室外機(1)は、執務室とB会議室を、室外 機(2)は、B会議室を除く会議室と受付、廊下が対象範囲で、室内機 （図中の $\square$ ）は、室外機(1)系統に13台、室外機(2)系統に7台設置さ れており、室内機ごとに制御可能である。各計測装置は5分間隔で 計測し、ゲートウェイを介してS-BEMSサーバに蓄積した。

また、アクティブ省エネ空調制御システム運用時には、各会議室 使用後に在室者が図6に示す着衣量、温冷感、快適感の申告を行っ た。会議日時、会議人数も併せて記入できるようにし、集計は会議 室毎に一日単位で行った。

次に、今回行った空調制御方法について述べる。表 2 に、会議室 で使用した各モードのテンプレートを示す。会議室管理システムか ら得た会議予約時間にもとづいて、会議開始 5 分前に予冷を実施し、 その後、各モードのテンプレートに従って間欠運転を行う。モード は、モード 1 からモード 7 までの 7 種類で、室内機の空調稼働時間 を $67 \%$ 17\%削減する。会議予約時間中は、テンプレートに従って、 空調が自動制御されるが、前述のように空調停止中に在室者によっ て空調が手動で ONされた場合には、次の自動停止時間までは空調 が稼働する。また、不在が 6 分継続した場合には空調を停止する。

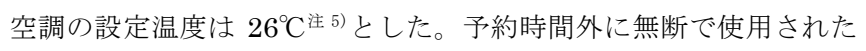
場合には、人感センサを利用した在不在にもとづく空調制御を行っ た。本実証実験では、実験初日（7 月 8 日）は、す心゙ての会議室で モード 4 に設定し、空調制御を開始した。翌日からは、零時に会議 室毎に、前日の手動 ON の回数から調整行動の回数を算出し、この 回数が 1 回/hr 未満の場合には 1 段階分稼働削減側のモードへ、 1 回/hr〜2 回/hr 未満では同じモードを維持し、2 回/hr 以上の場合に
表 1 建物概要

\begin{tabular}{|c|c|c|c|c|c|c|c|}
\hline \multicolumn{2}{|l|}{\begin{tabular}{|l} 
所在地 \\
用途 \\
\end{tabular}} & \multicolumn{2}{|l|}{$\begin{array}{l}\text { 東京 } \\
\text { 事務所ビル }\end{array}$} & \multicolumn{2}{|c|}{$\begin{array}{l}\text { 実施占有部面積 } \\
\text { 執務室面積 }\end{array}$} & \multicolumn{2}{|l|}{$\begin{array}{l}486.7 \mathrm{~m}^{2} \\
321.2 \mathrm{~m}^{2}\end{array}$} \\
\hline \multirow{3}{*}{\multicolumn{2}{|c|}{ 規模 }} & \multicolumn{2}{|c|}{ 地上10階、地下1階 } & \multicolumn{2}{|c|}{ 会議室総面積 } & \multicolumn{2}{|c|}{$165.5 \mathrm{~m}^{2}$} \\
\hline & & \multicolumn{2}{|c|}{ 延床面積 $8,664.09 \mathrm{~m}^{2}$} & & \multicolumn{2}{|r|}{$38.1 \mathrm{~m}^{2}$} \\
\hline & & & \multicolumn{2}{|c|}{ B会議室 } & \multicolumn{2}{|r|}{$21.6 \mathrm{~m}^{2}$} \\
\hline \multicolumn{2}{|c|}{ 基準階天井高 } & \multicolumn{2}{|l|}{$2.5 \mathrm{~m}$} & \multicolumn{2}{|c|}{$\mathrm{C}$ 会議室 } & \multicolumn{2}{|r|}{$15.7 \mathrm{~m}^{2}$} \\
\hline \multirow{4}{*}{\multicolumn{2}{|c|}{ 対象者 }} & \multicolumn{2}{|c|}{ 2010年：50名 (男性39,女性11) } & & D会議室 & \multicolumn{2}{|r|}{$15.7 \mathrm{~m}^{2}$} \\
\hline & & \multicolumn{2}{|c|}{ 2012年： } & & E会議室 & \multicolumn{2}{|r|}{$11.0 \mathrm{~m}^{2}$} \\
\hline & & \multicolumn{2}{|c|}{ 2013年 : 45名 (男性39,女性6) } & & F会議室 & \multicolumn{2}{|r|}{$63.4 \mathrm{~m}^{2}$} \\
\hline & & \multicolumn{4}{|c|}{ 職種 : ソフト／ハード設計・開発、営業、管理 } & & \\
\hline \multirow{2}{*}{\multicolumn{2}{|c|}{\begin{tabular}{|l|} 
空調システム \\
(吹出方式)
\end{tabular}}} & \multicolumn{6}{|c|}{ ビル用マルチ室内機 } \\
\hline & & \multicolumn{6}{|c|}{ （天井カセット方式） } \\
\hline \\
\hline \multirow{2}{*}{ 執務室 } & \multicolumn{2}{|c|}{ 定格(泠房時) } & \multicolumn{2}{|l|}{ 冷房能力 $(\mathrm{kW})$} & \multicolumn{2}{|c|}{ 消費電力(kW) } & $\mathrm{COP}$ \\
\hline & \multicolumn{2}{|c|}{ 室外機(1) (2台組) } & & 90 & & 26.9 & 3.04 \\
\hline エリア & 室内朴 & 機 13台 & & - & & 0.8 & - \\
\hline 会議室 & 室外 & 幾(2) (2台組) & & 56 & & 17.7 & 3.17 \\
\hline エリア & 室内杭 & 機 7台 & & -1 & & 0.5 & - \\
\hline
\end{tabular}

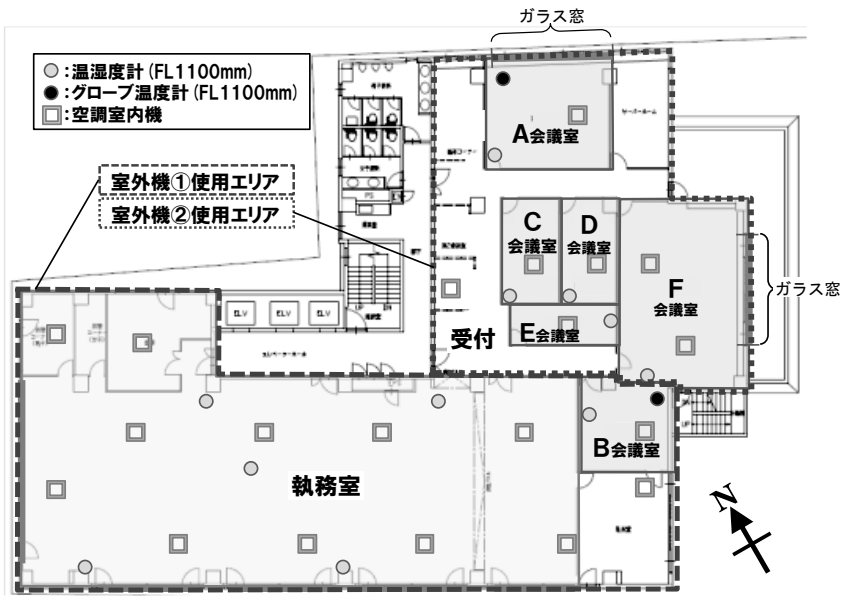

図 5 温湿度計、放射温度計設置位置と空調室内機設置位置

は 1 段階分稼働増加側のモード 一変更した。複数の室内機があ る場合には、室内機一台あたり の調整行動の回数として算出し た。なお会議室の予約外による 手動操作は解析対象外とした。 前日にアクティブ省エネ空調制 御が行われていない場合には、 最後に行われた日のモードを維 持する設定とした。

\section{2 温熱環境と空調稼働モ一 ドの変動状況}

\section{2.1 室内環境の時間変動}

図 7、図 8 に A 会議室の温度 変動状態を、会議人数、手動 $\mathrm{ON}$ 回数、PMV (温湿度 $=$ 計測 值、平均放射温度＝グローブ温 度から算出、着衣量=アンケー 卜結果、気流 $=0.1 \mathrm{~m} / \mathrm{s}$ 、活動量 =1.1 MET）とともに示す。各

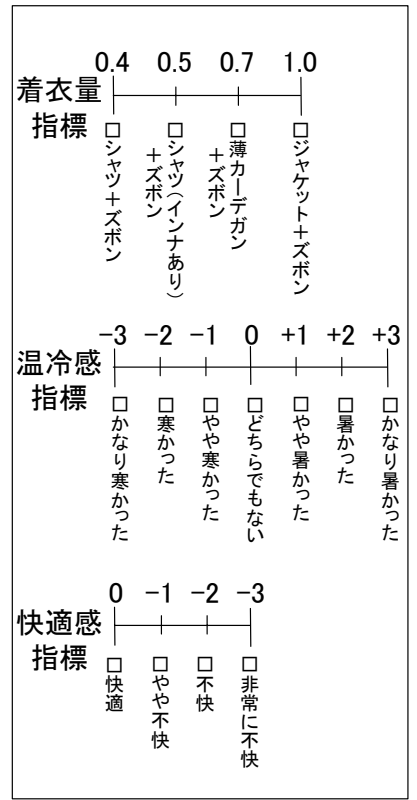

図 6 会議室使用後申告表 


\section{表 2 会議室用空調稼働モード（夏期実証実験）}

\begin{tabular}{|c|c|c|c|c|c|c|c|c|c|c|c|c|c|c|}
\hline \multirow{2}{*}{$\begin{array}{l}\text { 空調楊働 } \\
\text { モ一ト" }\end{array}$} & \multirow{2}{*}{$\begin{array}{l}\text { 見込み } \\
\text { 削堿率 } \\
\end{array}$} & \multicolumn{13}{|c|}{ 予約開始時刻からの相対時間での空調制御（単位・分） } \\
\hline & & -5 & 0 & 5 & 10 & 15 & 20 & 25 & 30 & 35 & 40 & 45 & 50 & 55 \\
\hline モード1 & $67 \%$ & ON & OFF & & ON & OFF & & ON & OFF & & ON & OFF & & ON \\
\hline モード2 & $58 \%$ & ON & OFF & ON & OFF & & ON & OFF & ON & OFF & & ON & OFF & ON \\
\hline モード3 & $50 \%$ & ON & OFF & ON & OFF & ON & OFF & ON & OFF & ON & OFF & ON & OFF & ON \\
\hline モード4 & $33 \%$ & ON & & & OFF & & ON & & & OFF & & ON & & \\
\hline モード5 & $33 \%$ & ON & & OFF & ON & & OFF & ON & & OFF & ON & & OFF & ON \\
\hline モード6 & $25 \%$ & ON & & & OFF & ON & & & OFF & ON & & & OFF & ON \\
\hline モード7 & $17 \%$ & ON & & & & OFF & ON & & & & OFF & ON & & \\
\hline
\end{tabular}

会議室は、室内機をスイングモードで運用しており、間欠運転され ているので、無風から断続的に気流を受ける環境であったが、PMV 算出には、気流を $0.1 \mathrm{~m} / \mathrm{s}$ とした。なお、アクティブ省エネ空調制 御期間を白抜きとした。

図 7 では、モード 6 (削減率 25\%) により制御されている。日中 は、室温に比べてグローブ温度が高く、空がある $\mathrm{A}$ 会議室は日射の 影響が大きいと推察される。9 時 30 分からの会議では、会議時間中 は調整行動が生じていない。室温 $27^{\circ} \mathrm{C} 、 \mathrm{PMV} 1.0$ 以下で、アクティ ブ省エネ空調制御による会議開始前 5 分間の予冷効果と、会議が 30 分程度と短時間で、会議人数も 6 名と少なかったためと考えられる。 その後、PMV が 1.0 の前後で調整行動が生じており、15 時 30 分〜 18 時 30 分の間では、 7 回の調整行動が検出された。この日のアク ティブ省エネ空調制御期間中の調整行動回数は 2.0 回/hr であった ので、翌日のモードは快適（稼働増加）側に移行した。

図 8 には、夏休み明けで最高気温が $34^{\circ} \mathrm{C}$ を超える日の温度変動状 態を示す。この日は、モード 7 （削減率 17\%）により制御されてい る。9 時 30 分からの会議では、休み明けのためで室温が $29^{\circ} \mathrm{C} 、 \mathrm{PMV}$ は 1.4 以上となり、空調が停止し温度が上がると手動による空調 ON 操作がなされた。会議終了後の室内気温は $31^{\circ} \mathrm{C} を$ 超えているが、 16 時からの会議では約 $0.5^{\circ} \mathrm{C}$ で温度変動しながら $28^{\circ} \mathrm{C}$ を概初維持し、 PMV は 0.89〜1.06 となっており、調整行動は見られなかった。こ の日の調整行動回数は、 0.7 回 $/ \mathrm{hr}$ であったので、翌日のモードは省 エネ（稼働削減）側に移行する。

以上のように、PMVが 1.0 近辺で調整行動が生じており、空調稼 働モードが環境条件に適応していない場合には、在室者による調整 行動によって室内環境が不快でない温熱環境に調整されていること がわかる。従って、調整行動は、会議室の環境条件等を含んだ、そ の時点での在室者の温熱要望として捉えることができると言える。 また、本システムでは、稼働モード選定のための判断基準として、 一日あたりの調整行動回数、寸なわち使用者の平均化された温熱要 望によって、翌日の空調を制御していることになる。しかしながら、 外気、躯体一の蓄熱、日射の違い、また、会議人数、会議時間、在 室者の属性の違いよって、室内の温熱環境は、時々刻々変化する。 従って、翌日の日射の影響や日変動には、手動操作によって温熱環 境の改善を図る必要がある。ただし、天気予報や外気温等の環境情 報を考慮してモード選定をすれば、また、在室者の人数や属性情報 を取得し判断基準に加味することができれば、より手動操作が少な い、在室者の温冷感、快適感に沿った省エネ空調制御が可能である と考えられる。

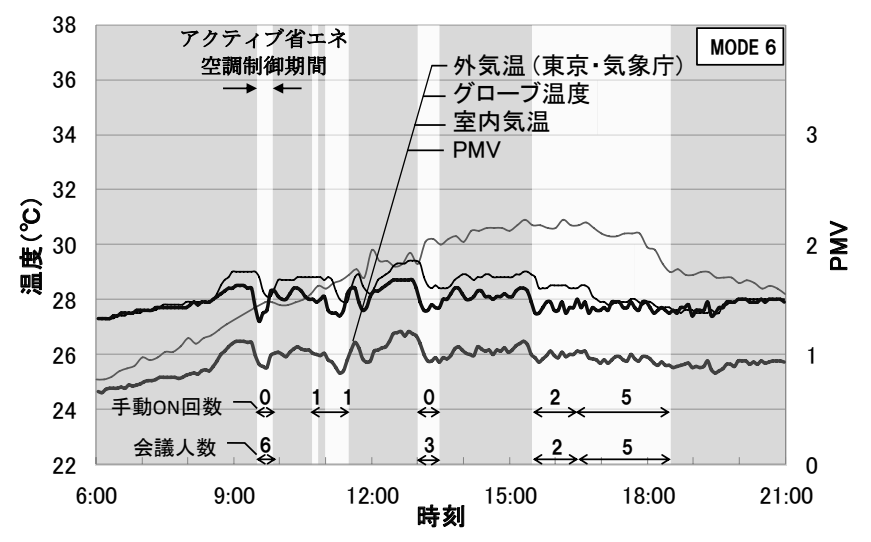

図 7 A 会議室の温度変動と空調稼働状態 (7 月 30 日)

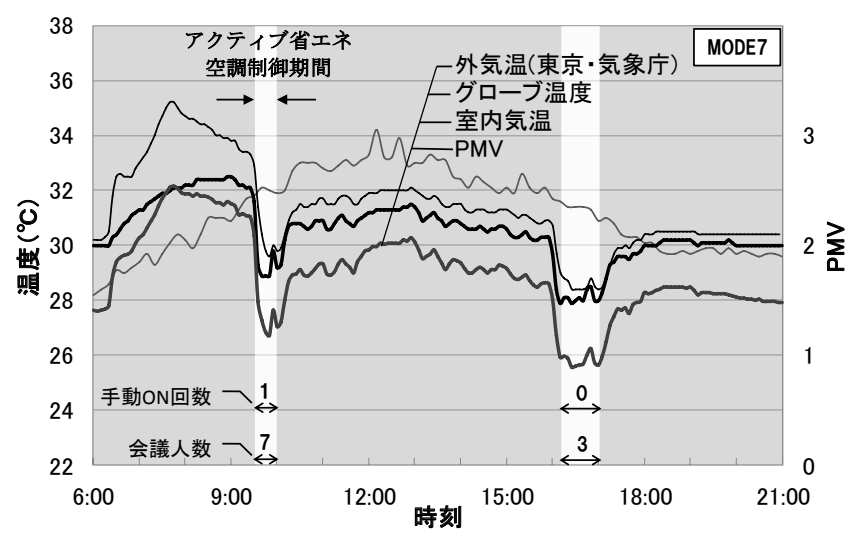

図 8 A 会議室の温度変動と空調稼働状態 (8 月 19 日)

\subsection{2 日変動とモードの切り替え}

図 9、図 10 に 7 月、8 月の $\mathrm{A}$ 会議室におけるアクティブ省エネ空 調制御時のモードの推移、室内気温（使用中のみの平均）、PMV（1 日平均）と外気温（東京）および、下式で算出した削減率差を示す。 なお、着衣申告が無い日のPMV は計算していない。また、休日お よび 7 月 26 日、 8 月 7 日および 27 日は、アクティブ省エネ空調制 御が実施されていないので、空欄としている。

削減率差 $[\%]=$ 空調稼働モード毎の見込み削減率 $[\%]$

$$
\text { 一実際の削減率[\%] }
$$

7 月 8 日の実験開始初日は、モード 4 で開始したが、実際の削減 率は設定した見込み稼働削減率よりも $24 \%$ 多くなり、その結果、翌 日のモードは、省エネ (稼働削減) 側のモード 3 となった。これは、 手動による OFF があり手動による空調 ON が少なかった結果で、 7 月 8 日の天候が雨天であった影響と考えられる。7 月 9 日は、調整 行動が 2.4 回/hr で翌 10 日は再びモード 4 に移行した。その後、最 高気温が $35^{\circ} \mathrm{C}$ 程度の暑い日が続き設定された削減率よりも多く空 調が稼働されているが、調整行動は 1 回/hr〜2 回/hr の範囲なので モード変化は生じていない。

一方、 7 月 16 日以降は、日平均外気温が $3^{\circ} \mathrm{C} \sim 6^{\circ} \mathrm{C}$ 程度低くなっ ているにもかかわらず、快適（稼㗢増加）側へと推移している。こ れは、 7 月 13 日までの記録的猛暑で躯体に蓄熱され、さらに 13 日 から 3 日間が休日で空調が稼働しなかった影響であると推察される。 その後、7月 23 日からは省エネ (稼働削減) 側へとモードが切り替 わっている。このように、アクティブ省エネ空調制御のモード切 

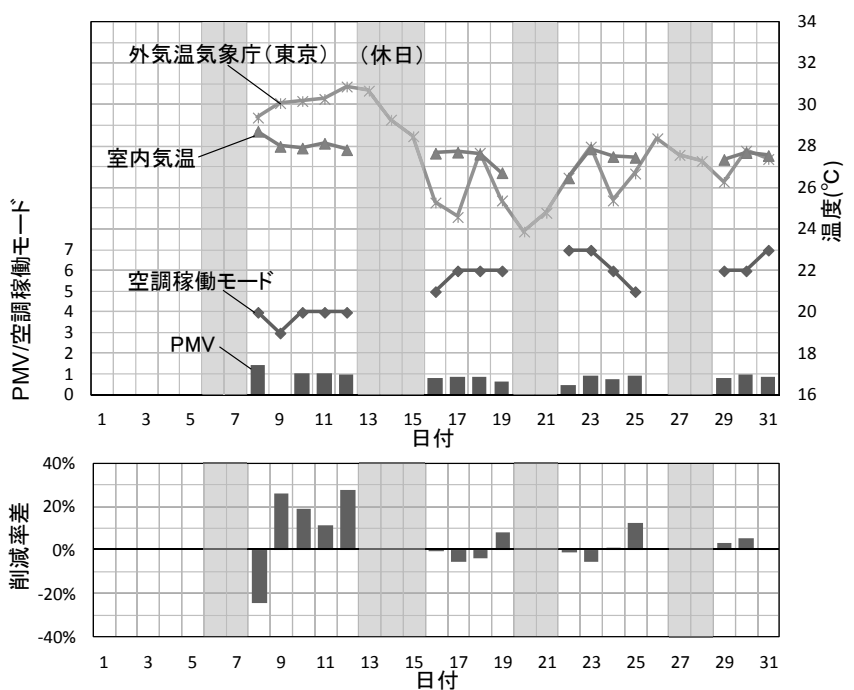

図 9 稼働状況と削減率差異 $A$ 会議室 $(7$ 月)
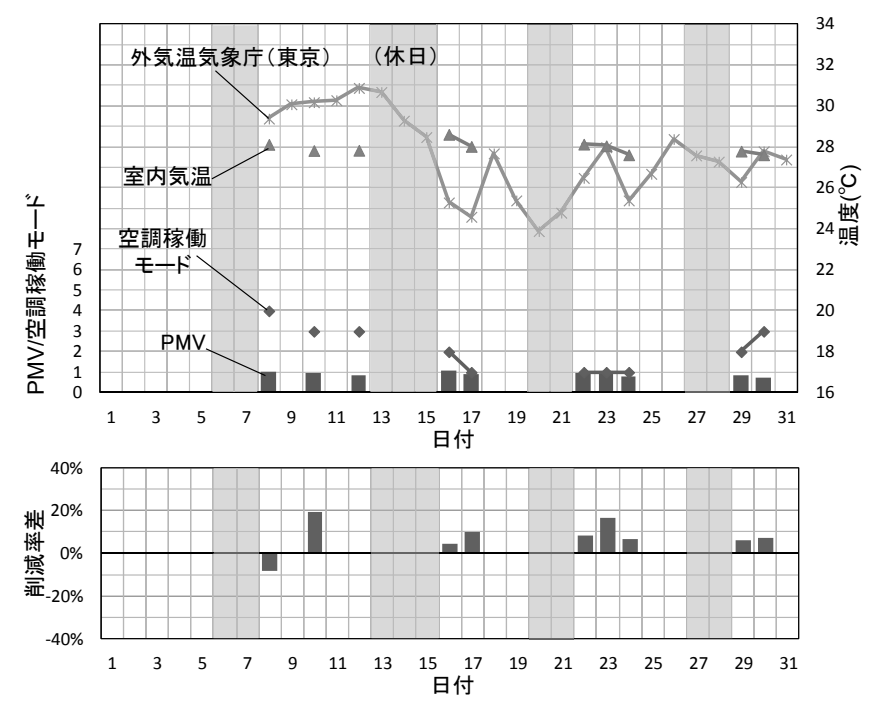

図 11 稼働状況と削減率差異 B 会議室 (7 月)

替えは、外気や躯体への蓄熱などの緩やかな温熱環境変化に対して は、追随していると言える。一方、PMVは、実験初日と 18 日のみ 1.0 を超えているが、その他は、 $0.3 \sim 1.0$ の範囲で制御されており、 アクティブ省エネ空調制御のモード変更が少ない 7 月 16 日〜 7 月 31 日の平均 PMV は 0.87 となっている。

図 9 に示寸A会議室の見込み削減率と実際の削減率との差は、制 御開始当初は大きいが、 7 月 16 日以降、実際の削減率との差は、ほ ぼ 10\%以内に収まっており、快適側や省エネ側へと、環境変化に合 わせてモードが切り替わることによって、調整行動が減少している ことが分かる。このように、アクティブ省エネ空調制御は、在室者 の調整行動によって、自動制御による無理な稼働削減（省エネ）を 抑制するとともに、その調整行動を空調制御にフィードバックする ことによって調整行動自体も減少させる。

図 10 に示寸 8 月においても、モードが外気温の変動に追随をし ている様子が伺える。削減率差が $10 \%$ 超える日が 5 日間あるが、 その他は $10 \%$ 以内で制御されており、また、PMVも 1.0 を超える
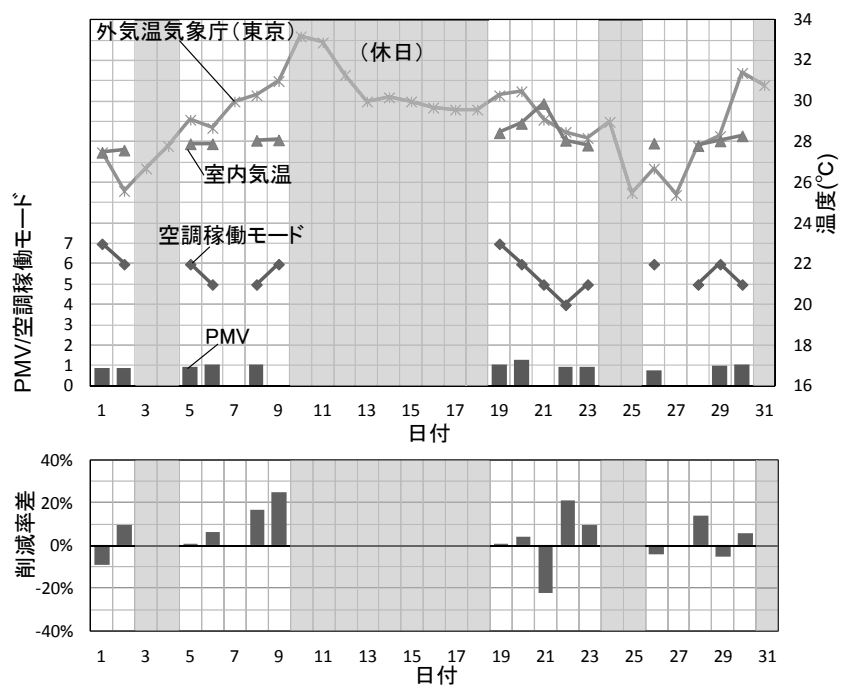

図 10 稼働状況と削減率差異 $A$ 会議室 (8 月)
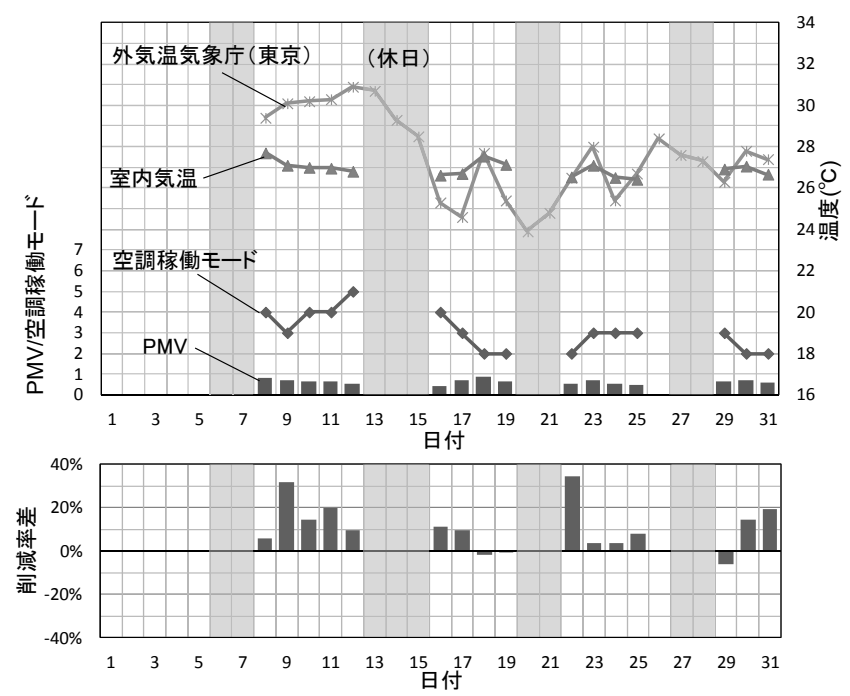

図 12 稼働状況と削減率差異 C 会議室 (7 月)

日が 2 日間あるが、およそ $0.7 〜 1.0$ の範囲にある。なお、この削減 率差異が $10 \%$ を超える日である 8 月 7 日〜 9 日、 8 月 20 日〜22 日、 8 月 27 日〜 28 日は、外気温が $2^{\circ} \mathrm{C} \sim 3^{\circ} \mathrm{C}$ 以上の変化を伴う比較的大 きな温度変化と休日明けであったことから、モードがこの環境変化 に十分に対応できなかったと考えられる。モードの変化量は土1 段 階/日である。その結果、1 段階分の増減では十分に室内環境に見 合った調整ができない場合に翌日も調整行動が 2 回/hr を超え、翌々 日もモードが室内環境を適正化する方向に切り替わる。例えば、 8 月 20 日は前日のモード 7 からモード 6 (省エネ側) に変更された が、外気温が $30^{\circ} \mathrm{C}$ 程度で手動 $\mathrm{ON}$ 回数が少なかったため翌 21 日も モード 5 に変更された。また、21 日は外気温が低下したため, さら にモード 4 へと変更されたが、2 2 日は、手動 ON 回数が増えてしま い、翌日は再びモード 5 一変更された。このように自動制御は、大 きな温度変化に対し、すぐに適応することはできないが、1〜2 日 遅れながら削減率差が減少する方向へと追随している。

\section{2.3 会議室による違い}




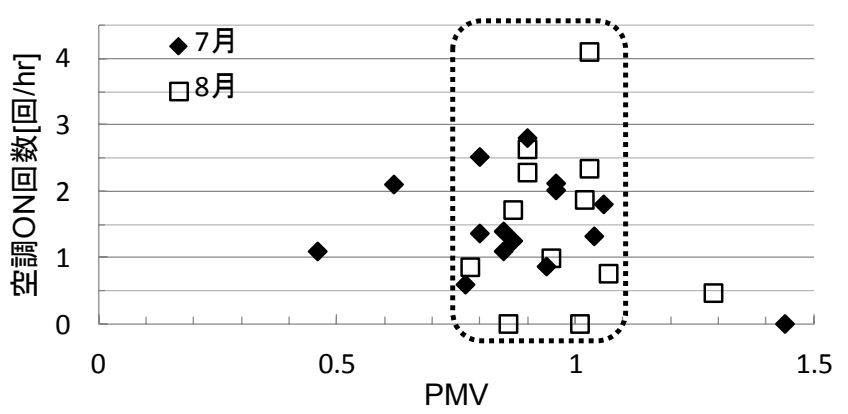

図 13 日平均 PMV と空調 ON 回数 A 会議室 (7月～8 月)

図 11 は、外壁はあるが空が無い B 会議室の結果を示す。A 会議 室と比較すると、全般的には調整行動が少なくモード 4 から 17 日 には、モード 1 (67\%削減) になった。これは、日射を受けないこ と、および 7 月中旬からの比較的涼しい気候の影響によるものと考 えられる。図 12 は、外壁の無い C 会議室の結果を示す。B 会議室 のようにモード 1 の日は無いが、17 日からはモード 2,3 で変動して おり、B 会議室と同様に外気温の変化にあまり影響されていない。 ビルの中央部に位置した会議室としての特徵が出ていると言える。 すなわち、各会議室を比較すると、空があり日射の影響を受ける A 会議室ではモードの変動が大きく、削減率はあまり多くはならない が、ビルの内部にあり外界の影響を受けない $\mathrm{B} 、 \mathrm{C}$ 会議室ではモー ドの変化は小さく、削減率は大きくなる傾向があることが分かる。

\section{2.4 温熱環境変化への追随性}

室内は、図 9〜12より、室温 $28^{\circ} \mathrm{C}$ 以下、PMV がほぼ 1.0 以下に て制御されていた。図 13 に、 7 月、 8 月の $\mathrm{A}$ 会議室における日毎の 平均 PMV（制御期間内）と空調 ON 回数（就業時間内）を散布図 として示寸。外部環境の変化に追随しながら空調稼働モードが変化 し、在室者の調整行動も日々異なるが、調整行動の回数は、空調 $\mathrm{ON}$ 回数が $1 \sim 2$ 回/hr (モード変更を行わない範囲) が多く、また、 室内温熱環境は、PMVで概ね $0.75 \sim 1.1$ に調整されていることが分 かる。

以上の結果より、アクティブ省エネ空調制御システムは、会議室 毎に在室者の属性、着衣量、温冷感、快適感、心理的状態は様々で はあるが、個々の調整行動の回数を求めることで総合評価としての 空調への要望を捉え、各会議室の固有の条件と緩やかな外気温の変 化に対応した空調制御を可能にすると考えられる。

一方、日射や一日以内の急激な温度変化には追随が難しく、アク ティブ省エネ空調制御を行っていない休日については、調整行動に よって前日の温熱環境が把握できないので、休日期間中の外気温変 動や蓄熱の影響には、素早く対応できないことも明らかになった。

\section{3 アンケート結果}

$\mathrm{A} 、 \mathrm{~B} 、 \mathrm{C}$ の3会議室における、7月、8月のアンケート回収率注6)、 室内平均気温注7)、申告された着衣量注8)、会議室の平均在室者数注9) を、表3、表4に示す。なお、会議室の使用者属性は、会議毎に集計 していなかったが、本実験での対象者(社員)は、男性39名、女性6 名であり、業務内容からも来客者は男性が多いと推察されるので、 殆どが男性であったと考えられる。

図14〜16に7月のA会議室、B会議室、C会議室の温冷感、快適感

\begin{tabular}{|c|r|r|r|r|r|r|r|}
\hline 会議室 & $\begin{array}{r}\text { 会議室 } \\
\text { 予約数 }\end{array}$ & $\begin{array}{c}\text { 実開催会議数 } \\
(\mathrm{A})\end{array}$ & $\begin{array}{l}\text { アンケート提出 } \\
\text { 会議数 (B) }\end{array}$ & $\begin{array}{c}\text { 回収率 } \\
(\mathrm{B} / \mathrm{A})\end{array}$ & $\begin{array}{c}\text { 出席者数 } \\
(\mathrm{C})\end{array}$ & $\begin{array}{l}\text { アンケート } \\
\text { 回収数 (D) }\end{array}$ & $\begin{array}{l}\text { 回収率 } \\
(\mathrm{D} / \mathrm{C})\end{array}$ \\
\hline $\mathrm{A}$ & 70 & 55 & 35 & $63.6 \%$ & 169 & 115 & $68.0 \%$ \\
\hline $\mathrm{B}$ & 38 & 27 & 22 & $81.5 \%$ & 118 & 76 & $64.4 \%$ \\
\hline $\mathrm{C}$ & 92 & 65 & 40 & $61.5 \%$ & 209 & 145 & $69.4 \%$ \\
\hline
\end{tabular}

2013/7月8-31日 (本制御の未実施日7/26を除く)

\begin{tabular}{|c|c|c|c|c|c|c|c|}
\hline 会議室 & $\begin{array}{l}\text { 会議室 } \\
\text { 予約数 }\end{array}$ & $\begin{array}{l}\text { 実開催会議数 } \\
\text { (A) }\end{array}$ & \begin{tabular}{|c|} 
アンケート提出 \\
会議数 $(\mathrm{B})$
\end{tabular} & \begin{tabular}{|c|}
$\begin{array}{l}\text { 回収率 } \\
(\mathrm{B} / \mathrm{A})\end{array}$ \\
\end{tabular} & $\begin{array}{c}\text { 出席者数 } \\
\text { (C) }\end{array}$ & $\begin{array}{l}\text { アンケート } \\
\text { 回収数 (D) }\end{array}$ & $\begin{array}{l}\text { 回収率 } \\
(\mathrm{D} / \mathrm{C})\end{array}$ \\
\hline A & 46 & 34 & 16 & $47.1 \%$ & 66 & 34 & $51.5 \%$ \\
\hline B & 26 & 24 & 20 & $83.3 \%$ & 122 & 88 & $72.1 \%$ \\
\hline $\mathrm{C}$ & 52 & 44 & 22 & $50.0 \%$ & 128 & 100 & $78.1 \%$ \\
\hline
\end{tabular}

2013/8月（本制御の未実施日 $8 / 7 、 27$ を除く）

表4 着衣量と在席者数

\begin{tabular}{|c|c|c|c|c|c|c|}
\hline \multirow{2}{*}{ 会議室 } & \multicolumn{3}{|c|}{ 着衣量 [clo] } & & \multicolumn{2}{|c|}{ 在室者数 [人] } \\
\hline & \multicolumn{2}{|c|}{ 7月 } & \multicolumn{2}{|c|}{ 8月 } & 7月 & 8月 \\
\hline \multirow{2}{*}{ A } & \multirow{2}{*}{0.56} & 最大 0.60 & \multirow{2}{*}{0.54} & 最大 0.60 & 4.69 & 4.13 \\
\hline & & 最小 0.50 & & 最小 0.50 & (分散 1.88) & (分散4.67) \\
\hline \multirow{2}{*}{$B$} & \multirow{2}{*}{0.55} & 最大 0.60 & \multirow{2}{*}{0.56} & 最大 0.65 & 5.36 & 6.10 \\
\hline & & 最小 0.50 & & 最小 0.50 & (分散6.78) & (分散4.89) \\
\hline \multirow[t]{2}{*}{$C$} & \multirow{2}{*}{0.56} & 最大 0.63 & \multirow{2}{*}{0.57} & 最大 0.60 & 5.23 & 5.82 \\
\hline & & 最小 0.50 & & 最小 0.54 & (分散 1.48) & (分散1.11) \\
\hline
\end{tabular}

の日毎の申告結果を示す。温冷感申告では、一日の各申告の割合を 「どちらでもない」を $0 \%$ 線の上下に均等に割り振り、その上側に「や や暑かった」「暑かった」「かなり暑かった」の順に、下側に「やや 寒かった」「寒かった」「かなり寒かった」の順に積み上げ棒グラフ として示した。快適感申告では、一日の各申告の割合を積み上げ棒 グラフとして示しており、図中の数字は各選択肢の申告数である。

$\mathrm{A}$ 会議室の温冷感申告結果（図14）では、実験開始当初は「やや 暑かった」「暑かった」と申告する在室者が多いが、7月16日以降は 「やや暑かった」が減り、「どちらでもない」が増えている。7月 22 日以降に「やや寒かった」の申告が若干あるが、総じて「どちらで もない」「やや暑かった」という申告が7割程度を占め、在室者の 心理的な評価からは、モードが在室者の求める温熱環境に近づくよ うな変化をしていることが分かる。但し、16日や29日〜30日など休 日明けの申告值は暑い側が多く、翌日のモードも稼働側に変化する 傾向がみられる。休日明けに設定されるモードは前週に設定されて いるので、休日間の変化にシステムが追随できていないことが温冷 感申告からも読みとれる。快適感の申告結果でも、実験当初「快適」 が少なく「やや不快」が多いが、モードが在室者の温冷感に適応し 始めた7月 16 日以降では、日毎の「快適」とする申告の割合が $40 \%$ 以上を占めており、「非常に不快」「不快」は少なくなっている。モ ードが環境条件に適応してきた 7 月 16 日〜 7月 31 日の総申告数にお ける「快適」の割合は $55.4 \%$ 、「やや不快」が $32.5 \%$ \%あった。

B会議室では、A会議室と比較して削減率が大きいモードで制御さ れており、特に中旬から下旬にかけてはモード1あるいは2で制御さ れていたが、「かなり暑かった」「暑かった」が減っている。「どちら でもない」が増えてはいないが、「やや暑かった」が大半を占める結 果となった。快適感の申告結果では、7月 16 日〜 30日の総申告数に おける「快適」の割合が $40.4 \%$ 、「やや不快」が50.9\%であり、A会 議室より「快適」が少ない。空調は、B会議室の温熱環境に応じて 制御されていたと推測するが、「やや不快」、「や暑い」の申告が多 くを占めた。この原因として、表 5 に示寸ように、気流速 $0.1 \mathrm{~m} / \mathrm{s}$ と 
して計算したA,B会議室の平均PMVはほとんど同じであることか ら、気流の影響が考えられる。すなわち、B会議室は、A会議室に比 べて外気温の影響を比較的受けない温熱環境であるものの、会議中 に空調が停止している時間割合が多く、在室者にとって無風に近い 状態が長く続く。その結果、「快適」が少なく、「やや暑い」という 割合が増えたと推察される。

$\mathrm{C}$ 会議室は、温冷感申告では、「どちらでもない」が50\%〜 80\%の 範囲で最も多く、快適感申告では、7月 16 日〜 30日の総申告数にお

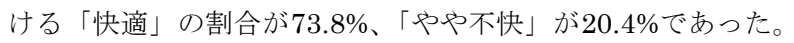

以上の結果から、アクティブ省エネ空調制御システムは、暑いと 感じた人に空調機の稼働を許可しているので、「非常に不快」「不快」 と回答する人を減らす。一方、「快適」な場合には調整行動が無いた め空調を削減する方向にモードを変更するので、「やや不快」を増や す制御となる。従って、このアンケート結果は、概衫妥当であると 言える。また、快適側、省エネ側へモード変更する調整行動回数の 閾值を小さく寸れば、空調稼働時間が増えて申告值が快適側に移行 する。この䦨值の調整によって、より快適で省エネな室内環境に近 づけることが可能であると考えられる。

図 17 に A 会議室の 7 月の温冷感、快適感、PMV の日毎の平均申 告值を示す。実験開始当初の 8 日〜 12 日までは、PMVが 1.0 程度 で、温冷感が 1.0 「やや暑い」近辺、快適感が-1.0「やや不快」近辺 であった。12 日以降は稼働側のモード 6 一推移し、モードが環境条 件に適応してきた 7 月 17 日以降は、温冷感が 0.5 近辺、快適感が-0.5 近辺に近づいており、在室者の温熱要望に沿った運用が行われてい ると考えられる。7 月 19 日は、調整行動が 2.1 回/hrで、翌日のモ ードを稼働側へ設定しているが、温冷感、快適感は悪くはない。こ れは、この日の運転がモード 6 であり、手動 ON 操作がなされた結 果、比較的快適な温熱環境になったと考えられる。25日も調整行動 は 2.8 回/hr と多いが温冷感、快適感は悪くはない。この結果から、 在室者が、内外部環境の変化に対してその時点での空調稼働モード に満足できない場合に調整行動が生じ、その調整行動は、室内の温 熱環境を改善寸るとともに、在室者の温冷感、快適感の申告值も改 善することが分かる。

一方、 7 月 30 日は、温冷感が 1.0 近辺、快適感が-1.0 近辺と悪い。 前日と比べて平均外気温が約 $2^{\circ} \mathrm{C}$ 上昇していたので、モード 6 の自 動運転に加えて、在室者の調整行動で温熱環境を改善する必要があ る。しかし、この日の調整行動 2.0 回/hr では、温熱環境の改善が充 分にされなかったと推定される。この結果から、設定した空調稼働 モードがその時点での環境条件と大きく離れていた場合、例えば、 外部環境が大きく変化した場合では、在室者が頻繁に調整行動をす る必要があるが、在室者が調整行動を控えてしまった場合には、我 慢の省エネとなり、結果的に温冷感、快適感の申告值が改善されな い場合もあると考えられる。

表 5 に、温冷感、快適感についての平均申告值と平均PMVを示す。 なお、8月は夏期休業日もあり対象日が11日と短い。A,B会議室は、 温冷感申告は、0.44〜0.68で「どちらでもない」と「やや暑かった」 の中間であり、C会議室は、0.14 0.43で「どちらでもない」に寄 った值であった。同じく $\mathrm{A}, \mathrm{B}$ 会議室の快適感は、 $-0.48 \sim-0.86$ と 「快適」と「やや不快」の中間であり、C会議室は、 $-0.29 \sim-0.59$ で「快適」に寄った值であった。在室者の申告による温熱環境は、
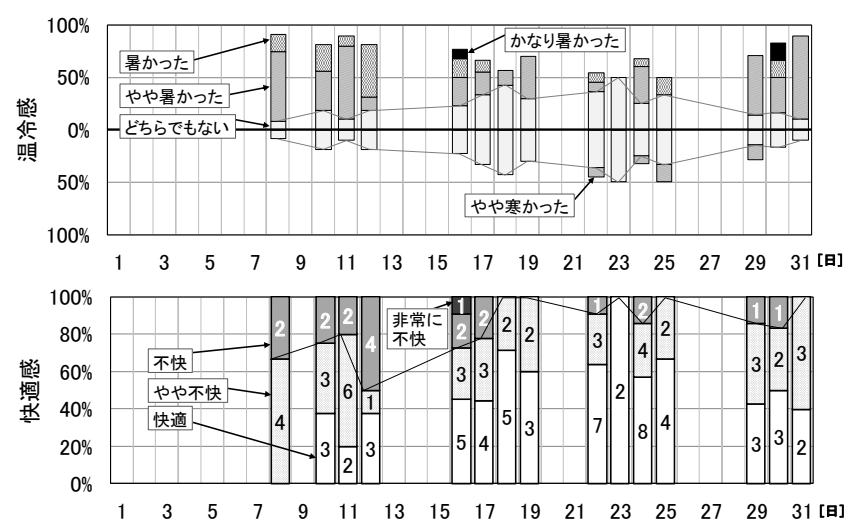

図14 アンケート結果 A会議室 (7月)
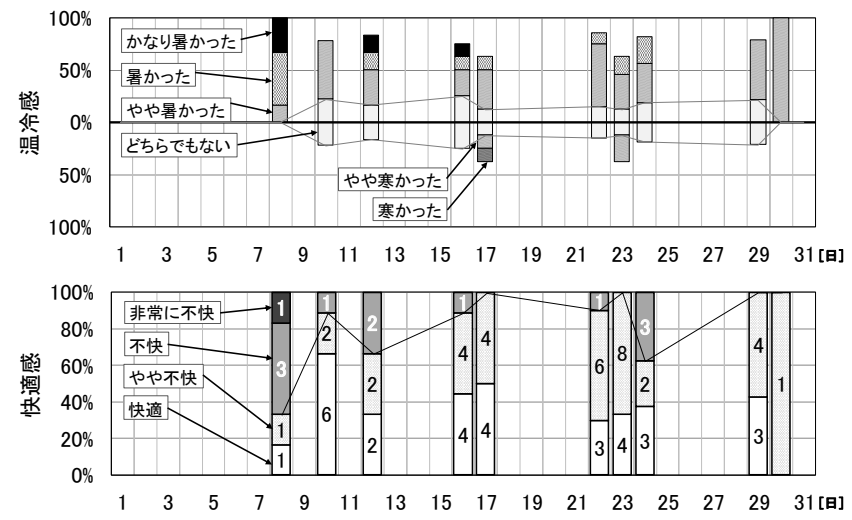

図15 アンケート結果 B会議室 (7月)
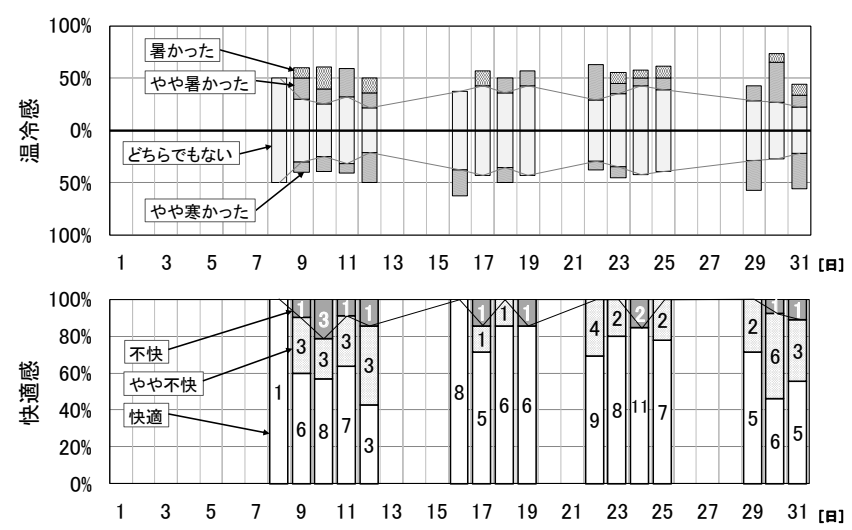

図16 アンケート結果 C会議室 (7月)

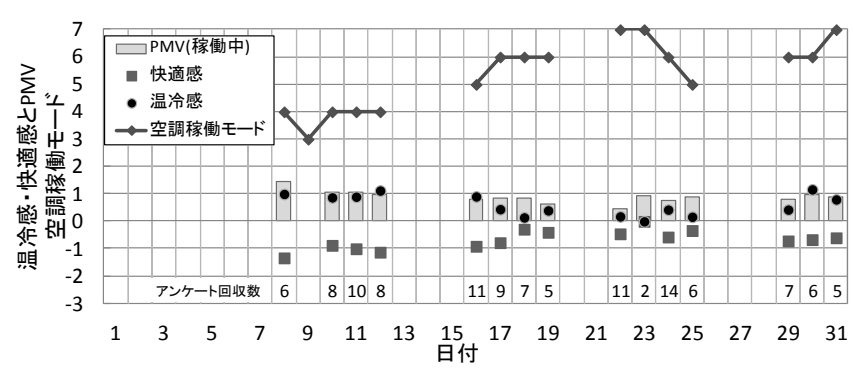

図17 温冷感、快適感申告結果 A会議室 (7月)

実測から算出した平均PMVに比べて、良い結果が得られた。これは、 PMVの申告尺度と本アンケートの申告尺度が違うことや、気流を $0.1 \mathrm{~m} / \mathrm{s}$ としてPMVを計算していることに起因すると考えられる。表 6 に空調稼働時の気流測定結果注10) を示す。風向が変化している状態 
表 5 温冷感、快適感申告結果

\begin{tabular}{|c|c|c|c|c|c|c|}
\hline \multicolumn{7}{|c|}{ 7月16日～7月31日(アンケート取得日を対象） } \\
\hline \multirow{2}{*}{ 会議室 } & \multicolumn{2}{|c|}{ 温冷感 } & \multicolumn{2}{|c|}{ 快適感 } & \multirow{2}{*}{ 平均PMV } & \multirow{2}{*}{ 平均PPD } \\
\hline & 平均申告値 & 分散 & 平均申告値 & 分散 & & \\
\hline A & 0.46 & 0.12 & 0.52 & 0.06 & 0.87 & 20.8 \\
\hline B & 0.53 & 0.13 & 0.58 & 0.12 & 0.88 & 21.7 \\
\hline $\mathrm{C}$ & 0.14 & 0.05 & 0.29 & 0.02 & 0.60 & 13.0 \\
\hline \multicolumn{7}{|c|}{ 8月1日～8月31日(アンケート取得日を対象） } \\
\hline \multirow{2}{*}{ 会議室 } & \multicolumn{2}{|c|}{ 温冷感 } & \multicolumn{2}{|c|}{ 快適感 } & \multirow{2}{*}{ 平均 PMV } & \multirow{2}{*}{ 平均PPD } \\
\hline & 平均申告值 & 分散 & 平均申告値 & 分散 & & \\
\hline A & 0.44 & 0.13 & 0.48 & 0.13 & 0.98 & 25.1 \\
\hline B & 0.68 & 0.14 & 0.86 & 0.26 & 1.00 & 26.2 \\
\hline C & 0.43 & 0.05 & 0.59 & 0.07 & 0.67 & 15.1 \\
\hline
\end{tabular}

*温冷感申告結果の7段階を-3から+3として日毎に平均值を求めた上で月毎に算出した *快適感申告結果の4段階を0から-3として日毎に平均値を求めた上で月毎に算出した *アクティブ制御期間の5分毎のPMVを日毎に平均值を求めた上で月毎に算出した

において三方向の気流を測定し、その測定結果から最少と最大を表 に示した。在室者への気流は変化しており、計算に用いた $0.1 \mathrm{~m} / \mathrm{s}$ より強い気流を受けている場合のあることが分かる。室温=放射温 度 $=28^{\circ} \mathrm{C}$ 、湿度 $=50 \%$ 、着衣量 $=0.55 \mathrm{clo}$ 、活動量 $=1.1 \mathrm{MET}$ 、気流 $=0.1 \mathrm{~m} / \mathrm{s}$ の時の PMV は、 0.91 であるが、気流が $0.4 \mathrm{~m} / \mathrm{s}$ になると PMV は 0.53 となる。従って、空調が稼働している時間では、気流 を受けることによって実際のPMV は、表 5 に示した PMV より小 さくなることが想定できる。そのため、空間に応じたモードによっ て制御を実施している効果や不快時に調整行動を行ったという満足 感に加え、調整行動をとることで直接的に気流を受けることができ ることも快適性を増加させる要因と考えられる。つまり、本システ ムは、空間的なパーソナル空調ではないが、不快な在室者に対して 時間的なスポット空調のような効果もあると考えられる。

\section{4 空調稼働削減結果}

テンプレートによる見込み削減率注11) と実際の空調稼働時間から 求めた空調稼働削減率を表7、表8に示す。調整行動によるフィード バックによってモードは日々変化しているが、7月、8月のすべての アクティブ省エネ空調制御期間を集計した。なお 7 月の最初の一週 間はアクティブ省エネ空調制御が追従するための期間として除外し た。その結果、7月の見込み削減率の平均は、A会議室は $25 \% 、 \mathrm{~B}$ 会 議室は $61 \%$ 、C会議室は $53 \%$ となり、それぞれの温熱環境や会議室 の使われ方に応じて異なる省エネ制御が実現されたことがわかる。 実際の削減率は、在室者による稼働によって設定值より少なくなり、 $\mathrm{A}$ 会議室は $24 \% 、 \mathrm{~B}$ 会議室は $52 \% 、 \mathrm{C}$ 会議室は46\%でとなった。調整 行動による空調稼働が加えられているものの、平均（3会議室）で $38 \%$ 稼働削減がアクティブ省エネ空調制御で実施できた。 8 月では、 外気温が高くなった影響が反映されており、7月に比べてすべての 会議室ともに削減率は減少し3会議室の平均で $29 \%$ とった。

\section{5 消費電力削減結果}

表 9 に $28^{\circ} \mathrm{C} て ゙$ 空調を連続稼働させていた 2010 年との消費電力の 比較を示す。2010 年は個々の空調機の消費電力は測定していなかっ たが、計測していた全空調消費電力と各室内機の稼働時間から空調 の電力量を推定した注12)。推定された総空調電力量は $11,945 \mathrm{kwh}$ で、 実測による $12,402 \mathrm{kwh}$ と約 4\%の誤差となり、この推定は妥当なも のと考えられる。この結果から、アクティブ省エネ空調制御で運用 した 2013 年の会議室エリアは、消費電力が 2010 年比で $62 \%$ 削減 されている。なお、外気温を 2010 年と比較すると、2013 年夏（東
表 6 会議室の気流測定結果

\begin{tabular}{|c|c|c|c|c|c|}
\hline & \multirow{2}{*}{ 測定場所 $* 1$} & \multicolumn{2}{|c|}{$\mathrm{X}, \mathrm{Y}, \mathrm{Z}$ 方向 $* 2$} & \multicolumn{2}{|c|}{ 4か所平均 } \\
\hline & & 最少 $[\mathrm{m} / \mathrm{s}]$ & 最大 $[\mathrm{m} / \mathrm{s}]$ & 最少 $[\mathrm{m} / \mathrm{s}]$ & 最大 $[\mathrm{m} / \mathrm{s}]$ \\
\hline \multirow{4}{*}{ A会議室 } & a & 0.12 & 0.88 & \multirow{4}{*}{0.05} & \multirow{4}{*}{0.68} \\
\hline & $b$ & 0.06 & 0.86 & & \\
\hline & c & 0.00 & 0.45 & & \\
\hline & d & 0.00 & 0.51 & & \\
\hline \multirow{4}{*}{ B会議室 } & $a$ & 0.11 & 0.43 & \multirow{4}{*}{0.10} & \multirow{4}{*}{0.47} \\
\hline & $b$ & 0.08 & 0.47 & & \\
\hline & c & 0.09 & 0.56 & & \\
\hline & d & 0.11 & 0.42 & & \\
\hline \multirow{4}{*}{ C会議室 } & $a$ & 0.08 & 0.40 & \multirow{4}{*}{0.09} & \multirow{4}{*}{0.45} \\
\hline & $b$ & 0.14 & 0.55 & & \\
\hline & c & 0.07 & 0.44 & & \\
\hline & $d$ & 0.05 & 0.42 & & \\
\hline
\end{tabular}

*1 測定場所 : 会議テーブル4隅の4座席位置、床面より $1100 \mathrm{~mm}$

*2 測定方向 : 座席正面を基準に、X方向: 前後、Y方向 : 左右、 $Z$ 方向 : 上下 空調がスイング稼働時にX,Y,Z方向の最少、最大の気流を測定し、その 中の最少と最大を抽出

表7 空調稼働削減結果（7月16日一31日）

\begin{tabular}{|c|r|r|r|r|r||r|}
\hline 会議室 & $\begin{array}{c}\text { 見込み } \\
\text { 削減率 }\end{array}$ & $\begin{array}{c}\text { 会議室 } \\
\text { 利用時間(h) }\end{array}$ & $\begin{array}{c}\text { 空調 } \\
\text { 稼働時間(h) }\end{array}$ & $\begin{array}{c}\text { 空調 } \\
\text { 稼働率 }\end{array}$ & $\begin{array}{c}\text { 空調稼働 } \\
\text { 削減率 }\end{array}$ & $\begin{array}{c}\text { 稼働 } \\
\text { 日数 }\end{array}$ \\
\hline $\mathrm{A}$ & $25 \%$ & 43 & 32 & $76 \%$ & $24 \%$ & 11 日 \\
\hline $\mathrm{B}$ & $61 \%$ & 21 & 10 & $48 \%$ & $52 \%$ & $7 日$ \\
\hline $\mathrm{C}$ & $53 \%$ & 42 & 23 & $54 \%$ & $46 \%$ & $11 日$ \\
\hline 合計 & $43 \%$ & 106 & 65 & $62 \%$ & $38 \%$ & \\
\hline
\end{tabular}

表8 空調稼働削減結果 (8月)

\begin{tabular}{|c|r|r|r|r|r||r|}
\hline 会議室 & $\begin{array}{c}\text { 見込み } \\
\text { 削減率 }\end{array}$ & $\begin{array}{c}\text { 会議室 } \\
\text { 利用時間(h) }\end{array}$ & $\begin{array}{c}\text { 空調 } \\
\text { 稼働時間(h) }\end{array}$ & $\begin{array}{c}\text { 空調 } \\
\text { 稼働率 }\end{array}$ & $\begin{array}{c}\text { 空調稼働 } \\
\text { 削減率 }\end{array}$ & $\begin{array}{c}\text { 稼働 } \\
\text { 日数 }\end{array}$ \\
\hline A & $26 \%$ & 33 & 27 & $81 \%$ & $19 \%$ & $15 日$ \\
\hline B & $51 \%$ & 28 & 16 & $55 \%$ & $45 \%$ & $10 日$ \\
\hline C & $31 \%$ & 37 & 28 & $75 \%$ & $25 \%$ & 15 日 \\
\hline \hline 合計 & $34 \%$ & 98 & 70 & $71 \%$ & $29 \%$ & \\
\hline
\end{tabular}

表9 空調電力量、室内機稼働時間の比較結果（7月－9月）

\begin{tabular}{|c|c|c|c|c|c|c|}
\hline & & & 2013年 & \multicolumn{2}{|c|}{ 2010年 } & \\
\hline \multicolumn{3}{|c|}{ 制御方式 } & $\begin{array}{l}\text { アクティブ } \\
\text { 空調制御 }\end{array}$ & \multicolumn{2}{|c|}{$\begin{array}{c}\text { 連続空調 } \\
\left(28^{\circ} \mathrm{C}\right)\end{array}$} & \\
\hline 室外機区分 & & & 実測値 & 実測値 & 推定値 & 削減率(\%) \\
\hline \multirow{4}{*}{$\begin{array}{c}\text { 室外機1 } \\
\text { 使用エリア } \\
\text { (執務室) }\end{array}$} & \multicolumn{2}{|c|}{ 室内機稼働時間(h) } & 3420 & 6374 & 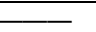 & \\
\hline & \multicolumn{2}{|c|}{ 室内機(kWh) } & 256 & & 476 & \\
\hline & \multicolumn{2}{|c|}{ 室外機(kWh) } & 4118 & & 7676 & \\
\hline & \multicolumn{2}{|c|}{ 空調電力量(kWh) } & 4374 & & 8152 & $46 \%$ \\
\hline \multirow{6}{*}{$\begin{array}{c}\text { 室外機(2) } \\
\text { 使用エリア } \\
\text { (会議室) }\end{array}$} & \multicolumn{2}{|c|}{ 室内機稼働時間(h) } & 1476 & 3866 & - & $62 \%$ \\
\hline & \multirow{2}{*}{ 内訳 } & 会議室 (5室)(h) & 1300 & 3301 & & $61 \%$ \\
\hline & & 受付·廊下用 $(h)$ & 176 & 565 & & $69 \%$ \\
\hline & \multicolumn{2}{|c|}{ 室内機(kWh) } & 53 & & 139 & \\
\hline & \multicolumn{2}{|c|}{ 室外機(kWh) } & 1395 & & 3654 & \\
\hline & \multicolumn{2}{|c|}{ 空調電力量(kWh) } & 1448 & & 3793 & $62 \%$ \\
\hline 全エリア & \multicolumn{2}{|c|}{ 空調電力量(kWh) } & 5822 & 12402 & 11945 & $53 \%$ \\
\hline
\end{tabular}

京）は、7月で0.7度低く、8月で0.4度低い。9月は0.1度高かった。 外気温が消費電力量へ与える影響は、図18に示寸外気温（東京）と 室外機の消費電力量の関係より $67.5 \mathrm{kwh} /$ 月 ・ ${ }^{\circ} \mathrm{C}^{\text {主13) }}$ となり、2010年 と比較した 3 力月間の削減電力量 $2,345 \mathrm{kwh}$ に比べて十分に小さい。 この削減の主な要因としては、まずA、C会議室の室内機の稼働が表 7、8のように 7 月が $24 \%$ と $46 \%$ 、8月が $19 \%$ と $25 \%$ 削減できているこ とが挙げられる。さらに、自動制御によって事前に会議室が予約さ 


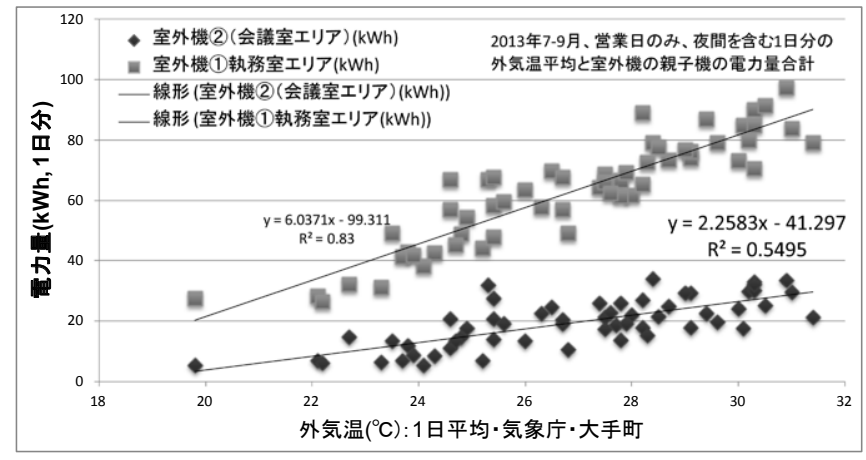

図18 外気温と室外機電力量

れていない時間の空調停止や人が不在になると空調を停止するとい う運用によって、無駄を無くした効果が大きいと考えられる。この 点については会議室の利用が減少したとも考えられるが、業務内容 の変化は無く、業務日数がともに 7 月から 9 月まで 58 日と同じで あり、在籍人員は $10 \%$ 減少していたが会議室という用途なので、極 端な使用状態の変化は無いと考えられる。

一方、表7〜 8よりアクティブ省エネ空調制御による空調稼働時間 は、65時間（7月16日〜31日）、70時間（8月）だが、予約時間以外 を含めた $\mathrm{A} \sim \mathrm{C}$ 会議室の室内機の合計稼働時間は、7月 16 日〜 31 日が 125 時間、8月が 233 時間となっており、予約時間以外の空調稼働時 間が多かったことが分かる。従って、予約時間以外の使用において もアクティブ省エネ空調制御をおこなうことで、さらなる電力削減 が可能と考えられる。

\section{4. まとめ}

本研究では、既存の中小規模建物にも導入可能な簡易な計測装置 と制御装置により、省エネによる室内環境の悪化を低減可能なアク ティブ省エネ空調制御システムについて検討している。このシステ ムは、在室者の調整行動を捉えて空調制御にフィードバックする。 本報では、このシステムの概要と夏期の実証実験結果を示した。以 下に、得られた主な知見を示す。

1）複数の会議室に対して、設定温度 $26^{\circ} \mathrm{C}$ とた空調でアクティブ 省エネ空調制御を実施した結果、空調稼働モードが環境条件に 適応すると、室温は、 $27^{\circ} \mathrm{C} \sim 28^{\circ} \mathrm{C}$ に維持され、気流を $0.1 \mathrm{~m} / \mathrm{s}$ と仮定した場合の全会議室平均PMVは $0.6 〜 1.0$ 、平均PPDは 13\%〜 26.2\%となった。アンケートによる申告では、温冷感は 0.14〜0.68（「どちらでもない」と「やや暑い」の区間）で寒 い側が無くやや暑い側に寄った結果となった。快適感は一0.29 〜-0.86で「快適」と「やや不快」の中央付近であった。

2） A,B,C会議室の空調室内機の稼働削減率は、19\% $52 \%$ で、 7 月は平均 $38 \%$ 、8月は平均 $29 \%$ となった。

3） A,B,C 会議室の比較により、外気や壁体への蓄熱などの建築条 件が異なる会議室に応じて、適切な空調の稼働削減を自動で実 現できることが示された。

4）会議室エリア全体では、室温設定 $28^{\circ} \mathrm{C}$ の連続空調であった 2010 年比で $62 \%$ の電力削減が達成できた。この原因として、 アクティブ省エネ空調制御による予約時間内での削減ととも に、空調機の消し忘れを防止した効果が大きいと考えられた。
5）在室者の空調ON/OFF操作から、在室者のその時点での室内環 境に対する温熱要望を捉えられることが示された。

6）在室者の調整行動によって、自動制御による無理な稼働削減を 抑制すると共に、その調整行動が減少するようにフィードバッ クすることで、より快適な温熱環境に向けた省エネ制御ができ ることが示された。

以上のように、在室者の調整行動を利用したアクティブ省エネ空 調制御によって個々の温熱環境に応じた省エネ制御が実現できるこ と、また、より快適な温熱環境に向けた制御の可能性が示された。

今後の課題として、調整行動回数が 1 日単位の算出のため、急激 な温度変化には対応できず、 2 日以上の緩やかな温熱環境の変化に しか追随ができないこと、また、休日への対応も必要であることが 明らかとなった。この対策としては、調整行動回数によるフィード バッグ周期を短くすることや翌日の天気予報を用いることで、より 追従性能の向上を図ることが考えられる。また、予約時間外の使用 について、アクティブ省エネ空調制御を適用できるようにする必要 があることも明らかになった。

なお、執務室のように複数の室内機がある場合への適用について も検討しており，今後発表する予定である。

\section{謝辞}

この研究は、独立行政法人新エネルギー・産業技術総合開発機構 省エネルギー革新技術開発事業（電力需給緊急対策）（「中小規模ビ ルでも容易に導入できるリアルタイムの節電目標を達成可能なフィ ードバック型電力需要制御システムの研究開発」) の研究助成を受け て実施した。ここに記し、関係者に謝意を示す。

\section{参考文献}

1）内閣官房 : 革新的エネルギー・環境戦略、

http://www.cas.go.jp/jp/seisaku/npu/policy09/pdf/20120914/20120914_ 1.pdf, pp.8-10 (参照 2014.2.10)

2）独立行政法人新エネルギー・産業技術総合開発機構：住宅・建築物高効 率エネルギーシステム導入促進事業（建築物に係るもの）・(BEMS導入支 援事業）平成11２1年度補助事業における成果の総合的分析， p. 201， 2011

3）坊垣和明、有川悦郎、福森幹太、角谷三夫、宮城啓史：パッシブリズミ ング空調における快適性と省エネルギーに関する研究（第1報）パッシブ リズミング空調が快適性に及ぼす影響に関する実験一夏期実験結果につ いて一, 空気調和・衛生工学会論文集, No. 64, 1997.1

4）宋: PAC空調機のスケジュールON/OFF制御による室内温熱環境と省エネル ギーに関する研究, 日本建築学会環境系論文集, N0. 633, pp.1283〜 1289, 2008. 11

5） 木下朋行：IT時代の計測・制御技術の動向 (2) PMV制御による室内環境最 適化制御，空気調和・衛生工学，80(3), pp. 213 220, 2006

6）空気調和・衛生学便覧 (第14版) : 空気調和・衛生工学会編, pp. 332 339, 2010

7）村上昌史、原田昌幸、久野覚、寺野真明：居住者の温熱要望申告を利用 した空調制御方式に関する研究, 日本建築学会環境系論文集, N0. 626, pp. 535 542，2008. 4

8）田中俊六他：建築環境工学 (三訂)，井上書院，1999

9) ASHRAE:ANSI/ASHRAE Standard, Thermal Environmental Conditions for Human Occupancy, 55-2004

10）荻野司、酒井浩介、須永修通 : 在室者の温冷感を利用した省エネ制御シ ステムの実証実験一夏季におけるオフィス内会議室における省エネ実験 から一，日本建築学会大会学術講演梗概集D-2，pp. 1047～1048，2013.8 
11）荻野司、酒井浩介、須永修通 : 在室者の調整行動を利用したアクティブ 空調制御システムによる室内環境と省エネ性能に関する研究（その 1 ） SaaS型BEMSの概要と夏期における空調制御結果, 太陽/風力エネルギー 講演論文集, N0161，pp. 591～594，2013. 11

12）増井修平、須永修通、荻野司、酒井浩介、: 在室者の調整行動を利用した アクティブ空調制御システムによる室内環境と省エネ性能に関する研究 （その 2 ）夏期における室内環境の実測およびアンケート結果，太陽/ 風力エネルギー講演論文集, N0162，pp. 595～598，2013.11

注

注1）調整行動を捉えるには空調の操作状態を取得する必要があるが、5分間 隔で空調発停リレーの状態を監視することにより代替し、別途制御装置 を付加していない。

注2）無線温湿度センサは、測定範囲: $-10^{\circ} \mathrm{C} \sim+60^{\circ} \mathrm{C}$, 測定精度: $\pm 0.5^{\circ} \mathrm{C}\left(+10^{\circ} \mathrm{C}\right.$ $\left.\sim+35^{\circ} \mathrm{C}\right), \pm 0.5 \% \mathrm{RH}\left(25^{\circ} \mathrm{C}, 60 \% \mathrm{RH}\right.$ に $)$, 分解能: $0.1^{\circ} \mathrm{C}$ 。 センサ部の設置 位置は、床面より $1100 \mathrm{~mm}$, 壁パーティション（金属製）より水平方向に $40 \mathrm{~mm}_{\circ}$

注3）グローブ球の直径は、A会議室: $7.5 \mathrm{~cm}, \mathrm{~B}$ 会議室: 直径 $15 \mathrm{~cm}$ 。注 2 の無線セ ンサを使用。設置位置は、床面より $1100 \mathrm{~mm}, \mathrm{~A}$ 会議室: 空面より水平方向 に $1000 \mathrm{~mm}$, B会議室:壁面より水平方向に $50 \mathrm{~mm}$ 。

注4）既設発停用リレーが無い場合、別途リレー敷設工事が必要。

注5）全ての室内機の設定温度は $26^{\circ} \mathrm{C}$ し、設定温度の変更はしていない。

注6）表 3 の会議室予約数は、会議室管理システムより得た。実開催会議数は、 予約された時間内に人感センサにより在室が確認された会議数。アンケ 一ト提出会議数は、予約された会議に一票でもアンケートが提出された 会議数。出席者数は、アンケートが提出された会議の会議人数の合計值。

注7）室内平均気温は、アクティブ省エネ空調制御が行われた期間の室内気温 の月平均気温。

注8）着衣量は、会議中の申告值（図6に示すクロ值）から、会議毎に平均化 し、その上で日毎に平均化して月別平均とした。

注9）平均在室者数は、会議毎に提出されたアンケートの会議人数を月平均し た。

注10)熱線式風速計 (SDカード記録), 測定範囲: $: 0.2 \mathrm{~m} / \mathrm{s} \sim 5.0 \mathrm{~m} / \mathrm{s}$, 測定精度: \pm $(5 \%$ 読取值 $+0.1 \mathrm{~m} / \mathrm{s})$, 分解能: $0.01 \mathrm{~m} / \mathrm{s}$, サンプリング時間 $: 1 \mathrm{sec}$

注11) 見込み削減率は、月次の事前予約による会議実施時間と見込み稼働時間 から算出した。見込み稼働時間は、事前予約による会議実施時間におけ る空調稼働モードと見込み空調稼働時間を日毎に算出して集計した。

注12)2013年（7月～9月）の実測結果より、室内機稼働 1 時間あたりの室内機 電力量、室外機電力量、空調電力量を求め、2010年の室内機稼働時間か ら2010年の各電力量を推定した。なお執務室エリアと会議室エリアでは、 室内機、室外機の仕様が異なるので、エリア毎に算出した。

注13)図18から外気温の変化における会議室(2)エリア室外機の消費電力変化 量は、2. $2583 \mathrm{kwh} /{ }^{\circ} \mathrm{C}$ であるので、一かを 30 日として $67.5 \mathrm{kwh} /$ 月・ ${ }^{\circ} \mathrm{C}$ と した。 


\title{
A STUDY ON ENERGY SAVING AIR-CONDITIONING CONTROL SYSTEM UTILIZING ADJUSTMENT BEHAVIOR OF OCCUPANTS
}

\author{
Tsukasa OGINO* , Kosuke SAKAI**, Satoshi SHIDA** \\ and Nobuyuki SUNAGA* \\ * Ubiteq, Inc. \\ Dept. of Architecture, Tokyo Metropolitan University, M. Eng. \\ ** Ubiteq, Inc. \\ *** Prof., Dept. of Architecture, Tokyo Metropolitan University, Dr. Eng.
}

Reduction of greenhouse gas emissions and increasing energy saving have become major societal issues. Measures to combat the former and optimize the latter have become especially urgent in Japan. Energy saving by whole societies, regardless of size, has been promoted through energy-saving actions on various types of facilities and buildings. However, energy management systems have been rather slowly introduced to small and medium-sized office buildings.

The present study examines a novel active energy-saving control system installed on a SaaS-type BEMS (Software as a Service-type Building Energy Management System). The system is easily introduced to small and medium-sized buildings, since a virtual BEMS can be configured to the building's physical equipment settings. Energy saving is achieved by active control of the indoor air-conditioning unit. The control system also reduces deterioration of the room conditioning by sensing the occupants' on/off switching of the air conditioning.

Ultimately, the system should satisfy the thermal comfort requests of the occupants by feedback of their adjustment behavior, rather than by collecting the details of the occupants' attributes, thermal and comfort sensations, and psychological conditions.

The experiment was conducted from $8^{\text {th }}$ July through $30^{\text {th }}$ September, 2013. The sites were the office area and conference rooms on the 6 th floor of a 10-story building in Tokyo. The results are summarized below:

1) Compared with the continuous running of air conditioning to maintain the temperature at $28^{\circ} \mathrm{C}$ in 2010 , the control reduced the energy usage by $62 \%$. The reduction is likely attributable to the active energy-saving control during the reserved period and to the air-conditioning automatically shuts off during inactive periods.

2) The occupants' thermal request for room conditioning was observed by the occupants' on/off switching behavior.

3) The system demonstrated the ability of providing a comfortable thermal environment by allowing active adjustment by the occupants. This feature counteracts over-reduction by automatic operation. In addition, the demands on occupants to adjust the system are reduced by feedback of the occupants' less active behavior.

Therefore, the proposed control system enables energy-economical control of the thermal conditions in individual conference rooms by sensing the occupants' adjustment behavior. The potential of the system to achieve a comfortable thermal environment has also been demonstrated.

In this paper, our proposed energy-saving system was evaluated in the office space of a medium sized building during the summer season. 